\title{
Molecular identification and distribution of native and exotic earthworms in New Zealand human-modified soils
}

\author{
Young-Nam Kim ${ }^{1}$, Nicholas Dickinson ${ }^{1}$, Mike Bowie ${ }^{1}$, Brett Robinson ${ }^{2}$ and Stephane Boyer ${ }^{1,3^{*}}$ \\ ${ }^{1}$ Department of Ecology, Lincoln University, Lincoln 7647, Christchurch, New Zealand \\ ${ }^{2}$ Department of Soil and Physical Sciences, Lincoln University, Lincoln 7647, Christchurch, New Zealand \\ ${ }^{3}$ Applied Molecular Solutions Research Group, Environmental and Animal Sciences, Unitec Institute of Technology, \\ Private Bag 92025, Victoria Street West, Auckland 1142, New Zealand \\ *Author for correspondence (Email: sboyer@unitec.ac.nz)
}

Published online: 1 March 2017

\begin{abstract}
Important knowledge gaps remain with regards to the ecology and the systematics of New Zealand's native earthworms. With many putative new species yet to be described, often specimens cannot be named, which makes species inventory, monitoring and community comparisons difficult. Our work aimed to identify new putative taxa of New Zealand native species of earthworms, and describe their distribution in selected human-modified ecosystems. A total of 24 earthworm taxa (13 native and 11 exotic) were identified using a DNA barcoding approach focusing on 16S rDNA and COI (cytochrome oxidase subunit 1). The combination of morphological and molecular analyses were complementary in elucidating species identity. However, of the 13 native taxa, eight could not be named and are likely to be undescribed species from the genera Octochaetus, Maoridrilus and Deinodrilus. Most native species appeared to have a restricted geographic distribution linked to soil conditions, in particular $\mathrm{pH}$ and organic matter.
\end{abstract}

Key words: 16S; COI; DNA barcoding; Lumbricidae; Megascolecidae; native earthworms; phylogeny

\section{Introduction}

Since the arrival of Polynesians c. 750 years ago, more than two-thirds of New Zealand's native forests and grasslands have been replaced by human-modified landscapes, resulting in depauperation of native fauna including earthworms. Following conversion of native habitat to agriculture, native earthworm communities have largely disappeared from newly established farmland (Lee 1961). Introduced European Lumbricidae (mainly Aporrectodea caliginosa, A. longa, A. rosea, A. trapezoides, Lumbricus rubellus, and Octolasion cyaneum) with more tolerance to environmental disturbances have become dominant (Lee 1985; Fraser et al. 1996; Springett et al. 1998). Native species in the Megascolecidae family are often restricted to protected habitats and remnants of native vegetation, but they are also found on the borders of agricultural land (Kim et al. 2015). Coexistence of native and exotic species has recently been reported where patches of native vegetation borders agricultural land (Kim et al. 2015; Bowie et al. 2016) or when native vegetation is restored on agricultural land (Boyer et al. 2016).

Of the 3700 species of terrestrial earthworm described worldwide, 173 were described in New Zealand prior to 2000 (Blakemore 2006; Glasby et al. 2009). The earthworm species list was mainly the result of Lee's monograph published in the late 1950s (Lee 1959a). Despite an extensive geographical coverage of New Zealand, Lee's work was restricted to areas that were relatively easily accessible at that time. As a result, recent studies have unearthed a number of putative undescribed native species particularly in remote locations where no previous searches had been conducted (Boyer et al. 2011; Buckley et al. 2011).

In many cases, research on earthworm taxonomy has been limited by a lack of standardised morphological characters, phenotypic variability, and difficulties in defining diagnostic characters at juvenile or cocoon stages (Decaëns et al. 2013). Some of these taxonomic difficulties may be alleviated by recent developments in imagery for the description of internal morphology using Micro-Computed Tomography (Fernández et al. 2014), but lack of taxonomic expertise remains limiting. In recent years, the introduction of DNA barcoding has effectively aided species discrimination, identification of new taxa, reconstruction of phylogeny, and biodiversity assessments in numerous invertebrate groups, including earthworms (King et al. 2008; Chang \& James 2011; Decaëns et al. 2013). DNA barcoding can be particularly useful for resolving previous taxonomic confusion but also to accelerate new taxonomic acts. For example, a new species of Hormogaster (H. abbatissae) was reported by Novo et al. (2010) based on the combination of morphological information and phylogenetic position following DNA barcoding. Moreover, molecular tools can be used to support phylogeography analysis for single species or a group of closely related species (e.g. Chang \& Chen 2005; Minamiya et al. 2009) as well as discriminating between native and exotic species (Cameron et al. 2008; Porco et al. 2013). In conjunction with phylogenetic analyses, DNA barcoding analyses not only contribute to the discovery of new species and the identification of specimens, but also enhance our understanding of earthworms' ecology, taxonomy and evolutionary history (Domínguez et al. 2015).

Due to its unique geography, New Zealand is potentially home to many yet to be described Megascolecidae inhabiting isolated remnants of undisturbed native vegetation (SB unpubl. data). Buckley et al. (2012) anticipated that about 100 cryptic taxonomic species may remain to be described and molecular tools are now instrumental to the taxonomic description of native earthworms in New Zealand. Boyer et al. (2011) used DNA barcoding and phylogenetic analyses (based on the 16S 
rDNA and COI genes) to support their description of three new species of Megascolecidae (Deinodrilus gorgon, Ma. felix, Octochaetus kenleei).

The primary aim of this study was to identify New Zealand native earthworms, including undescribed species, through DNA barcoding and describe their occurrence, as well as that of introduced species, in human-disturbed soils in relation to soil physicochemical properties.

\section{Materials and methods}

\section{Earthworm sampling}

Earthworm collection was undertaken between 2012 and 2015 in remnants of native vegetation and at a number of restoration areas in the South Island of New Zealand (Table 1). The 13 sampling sites were located at Banks Peninsula, Bankside, Eyrewell and Lincoln in Canterbury; and Punakaiki on the West Coast. To avoid the dry season when soil is hard to excavate and earthworms are more difficult to find, sampling took place mostly between late autumn (May) and the beginning of summer (December).

Soil pits $(20 \times 20 \times 20 \mathrm{~cm})$ were dug using a spade and earthworms were hand-sorted in the field. Collected earthworms were brought back to the laboratory for morphological identification following Lee $(1959 \mathrm{a}, \mathrm{b})$ as well as for DNA analysis and other experimental work. Specimens were first categorised into morphospecies based on their external morphology, size, colour and behaviour. A total of 32 specimens representing all morphospecies were then analysed through DNA barcoding using the COI and $16 \mathrm{~S}$ genes in an attempt to confirm species status.

\section{DNA extraction, PCR and sequencing}

Molecular analyses were conducted following a modified method from Boyer et al. (2011). Earthworms were washed in distilled water, then tissue samples (muscular body wall) were taken from behind the clitellum (mostly the tip of the tail) and preseved in $98 \%$ ethanol. Genomic DNA was extracted using a GF-1 Tissue DNA extraction kit (Vivantis Technologies Sdn. Bhd., Malaysia) following the manufacturer's recommendation. DNA was eluted in $200 \mu \mathrm{l}$ preheated elution buffer and stored at $-20^{\circ} \mathrm{C}$ until further analysis.
Universal invertebrate primers for 16S (LR-J-12887 and LR-N-13398; Simon et al. 1994) and COI (LC01490 and HC02198; Folmer et al. 1994) were used to amplify 550 and $\sim 650$ base pair fragments of DNA respectively (see Table $S 1$ in Supplementary Material). PCR reactions $(10 \mu \mathrm{l})$ consisted of 5 $\mu 1$ GoTaq ${ }^{\circledR}$ Green Master Mix (Promega, Madison, WI, USA), $0.1 \mu \mathrm{MgCl}_{2}$ [25 mM], $0.4 \mu \mathrm{l}$ forward and reverse primers [10 $\mu \mathrm{M}], 1.5 \mu \mathrm{l}$ DNA template and $2.6 \mu \mathrm{l}$ DNA-free water. The thermocycling protocol comprised of an initial denaturation at $95^{\circ} \mathrm{C}(4 \mathrm{mins}), 35$ cycles of denaturation at $94^{\circ} \mathrm{C}(1 \mathrm{~min})$, annealing at $52^{\circ} \mathrm{C}(1 \mathrm{~min})$ and elongation at $72^{\circ} \mathrm{C}(1.5 \mathrm{mins})$, followed by a final elongation at $72^{\circ} \mathrm{C}(10 \mathrm{mins})$. Negative controls were included to detect potential contamination. PCR products were sequenced in both directions using BigDye ${ }^{\circledR}$ Terminator Cycle Sequencing Kit following the manufacturer's protocol (Thermo Fisher).

\section{Delineation of molecular taxonomic units (MOTUs)}

All DNA sequences generated as part of this study were submitted to the GenBank database (accession numbers: KP771668-KP771678, KP780261-KP780262, KP828823KP828824). Sequences were manually edited using FinchTV 1.40 (Geospiza), and compared to existing sequences in the Genbank database as well as sequences from Buckley et al. (2011) and Boyer (2013). The sequences generated here and their best match in the existing databases were exported into MEGA6 (Tamura et al. 2013) and Geneious ${ }^{\circledR} 6.1 .8$ (Biomatters) for alignment using MUSCLE (Edgar 2004). This resulted in alignments of 49 sequences for COI and 48 sequences for $16 \mathrm{~S}$. Neighbour-Joining trees (Saitou \& Nei 1987) were then prepared and p-distances were calculated to make taxonomic decisions. The R package SPIDER (Species Identity and Evolution in R) was used to determine species boundaries and estimate the number of species present (Brown et al. 2012). The threshold for interspecific distances was calculated using the function localMinima in SPIDER (Brown et al. 2012).

\section{Soil analyses}

Soil analyses were performed at eight of the 13 sampling sites (Table 1). To elucidate soil properties at those collection sites, $500 \mathrm{~g}$ of fresh soil was sampled from the pits at the time of earthworm sampling. All soils were analysed by Analytical

Table 1. Earthworms sampling sites and GPS coordinates. Punakaiki is located on the West Coast while the other four sampling sites are located in Canterbury.

\begin{tabular}{|c|c|c|c|}
\hline \multicolumn{2}{|l|}{ Sampling sites } & \multirow{2}{*}{$\begin{array}{l}\text { Location (latitude/longitude) } \\
-42^{\circ} 8^{\prime} 38.39^{\prime \prime} \mathrm{S} / 171^{\circ} 19^{\prime} 50.36^{\prime \prime E}\end{array}$} & \multirow{2}{*}{$\begin{array}{c}\text { Sites where soil samples were collected } \\
\checkmark\end{array}$} \\
\hline Punakaiki & Nikau Reserve & & \\
\hline P पпनKaाkI & Restored and unplanted land & $-42^{\circ} 8^{\prime} 26.74 " \mathrm{~S} / 171^{\circ} 19^{\prime} 47.53^{\prime \prime E}$ & $\checkmark$ \\
\hline Bankside & Bankside Scientific Reserve & $-43^{\circ} 43^{\prime} 49.33^{\prime \prime} \mathrm{S} / 172^{\circ} 09^{\prime} 34.60^{\prime \prime} \mathrm{E}$ & \\
\hline \multirow{6}{*}{ Banks Peninsula } & Okuti Reserve & $-43^{\circ} 47^{\prime} 07.98^{\prime \prime} \mathrm{S} / 172^{\circ} 49^{\prime} 51.23^{\prime \prime} \mathrm{E}$ & $\checkmark$ \\
\hline & Bossu Road & $-43^{\circ} 48^{\prime} 59.93^{\prime \prime S} / 172^{\circ} 51^{\prime} 49.46^{\prime \prime} \mathrm{E}$ & $\checkmark$ \\
\hline & Southern Summit Roadside & $-43^{\circ} 44^{\prime} 15.41^{\prime \prime S} / 172^{\circ} 54^{\prime} 32.64^{\prime \prime E}$ & $\checkmark$ \\
\hline & Kaituna Reserve & $-43^{\circ} 44^{\prime} 37.23^{\prime \prime S} / 172^{\circ} 41^{\prime} 14.82^{\prime \prime E}$ & $\checkmark$ \\
\hline & Ahuriri Reserve & $-43^{\circ} 39^{\prime} 58.97^{\prime \prime} \mathrm{S} / 172^{\circ} 37^{\prime} 26.37^{\prime \prime} \mathrm{E}$ & $\checkmark$ \\
\hline & Northern Summit Roadside & $43^{\circ} 39^{\prime} 59.86^{\prime \prime S} / 172^{\circ} 37^{\prime} 28.63 " \mathrm{E}$ & $\checkmark$ \\
\hline \multirow{2}{*}{ Eyrewell } & DOC Scientific Reserve & $-43^{\circ} 22^{\prime} 59.07^{\prime \prime} \mathrm{S} / 172^{\circ} 11^{\prime} 39.78^{\prime \prime} \mathrm{E}$ & \\
\hline & Spencer Bower Reserve & $-43^{\circ} 25^{\prime} 42.08^{\prime \prime} \mathrm{S} / 172^{\circ} 25^{\prime} 48.10^{\prime \prime} \mathrm{E}$ & \\
\hline \multirow{2}{*}{ Lincoln } & Liffey Spring & $-43^{\circ} 38^{\prime} 18.64^{\prime \prime S} / 172^{\circ} 29^{\prime} 06.93^{\prime \prime E}$ & \\
\hline & Lincoln University & $-43^{\circ} 38^{\prime} 37.19^{\prime \prime S} / 172^{\circ} 27^{\prime} 43.77^{\prime \prime E}$ & \\
\hline
\end{tabular}


Services in the Department of Soil and Physical Sciences at Lincoln University using standard methodologies, with ASPAC Ring Test QA procedures. Available nitrogen was analysed on fresh soil following extraction with $2 \mathrm{M} \mathrm{KCl}$ (Blakemore 1987) and was determined using a FIA star 5000 triple channel analyser (Foss Tecator AB, Sweden). The remaining soil was air-dried and sieved to $<2 \mathrm{~mm}$ using a stainless steel sieve for further soil chemical analysis. Soil $\mathrm{pH}(1: 5 \mathrm{~W})$ and electrical conductivity (EC) were measured using $\mathrm{pH}$ and $\mathrm{EC}$ meters (Mettler Toledo Seven Easy). For organic matter(OM) content, $10 \mathrm{~g}$ of oven dried $\left(100^{\circ} \mathrm{C}\right)$ soil was processed through loss on ignition at $550^{\circ} \mathrm{C}$ in a muffle furnace (Blakemore 1987).

\section{Statistical analysis}

Soil properties, such as $\mathrm{pH}, \mathrm{EC}, \mathrm{OM}$ content and mobile nitrogen $\left(\mathrm{NH}_{4}{ }^{+}\right.$and $\left.\mathrm{NO}_{3}{ }^{-}\right)$, were analysed using one-way ANOVA followed by a Fisher's least-significant-difference post-hoc test. Data were analysed using Minitab 17 (Minitab Inc., State College, Pennsylvania, USA).

\section{Results}

\section{Specimen identification}

Species delineation thresholds calculated for the COI and $16 \mathrm{~S}$ genes were $3 \%$ and $2.8 \%$, respectively, meaning that specimens of a similar species have at least $97 \%$ similarity in their COI DNA sequence, and at least $97.2 \%$ similarity in their 16S DNA

$\mathrm{COI}$

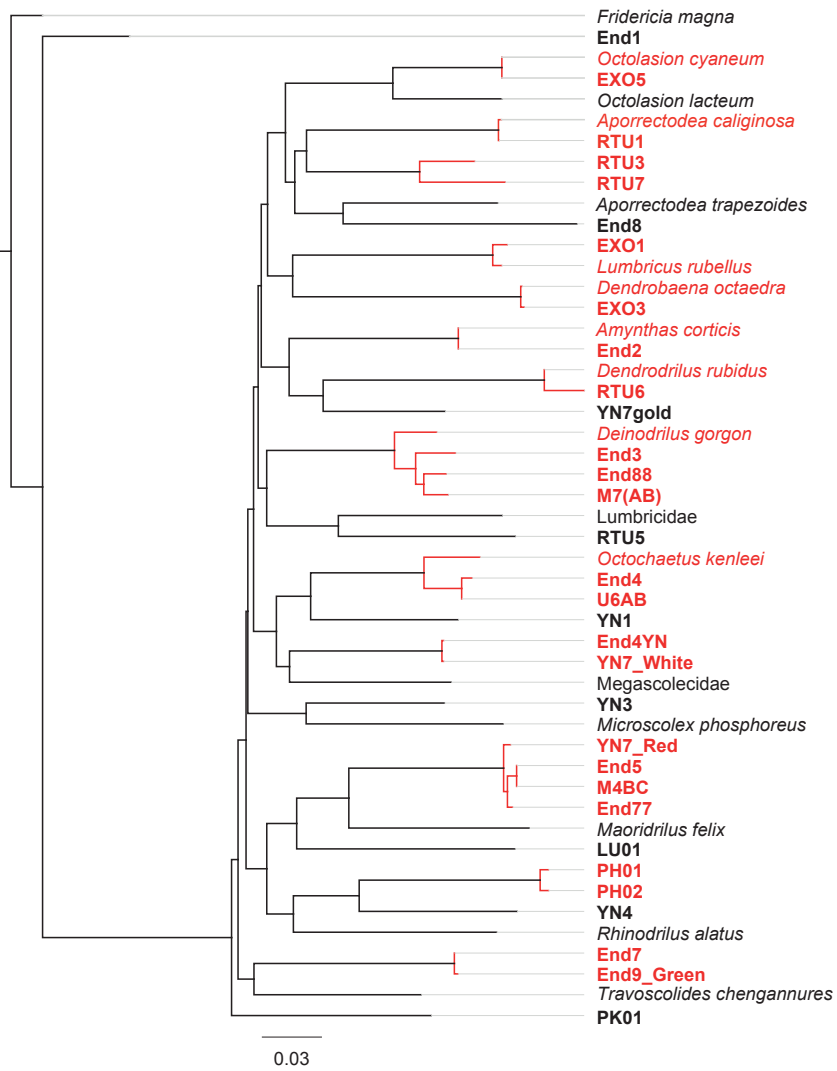

sequence. Based on these thresholds, 24 discrete taxa were identified from the 36 individuals analysed (Fig. 1).

Only two specimens could be confidently identified at species level using morphological characteristics. They belonged to the native Megascolescidae species: Octochaetus multiporus and Ma. transalpinus (Table 2). Eight more specimens could be identified at genus level based on their morphology: Octochaetus, Maoridrilus, and Deinodrilus. When using DNA analyses, 11 specimens could be identified at species level from their $16 \mathrm{~S}$ sequence, and the same was true for COI although the specimens that could be identified by each marker were different. The combination of both molecular markers and morphology led to the identification of 17 specimens at species level, and three at genus level, leaving 16 specimens unidentified. Despite slight differences in the datasets and the trees, the analysis of COI and 16S sequences provided no contradictory diagnostic in terms of species identification (Fig. 1, Table 2).

\section{Earthworm distribution and soil chemistry}

A total of 13 native and 11 exotic taxa were sampled across all study sites with richness at the different sites ranging from two to six taxa (Fig. 2, Table S2 in Supplementary Material). The Punakaiki restoration area contained the greatest richness of native earthworms (six taxa) in the Nikau Reserve and the greatest richness of exotic earthworms (eight taxa) in the restored land. Five of the 13 sites had a mixture of native and exotic earthworms.

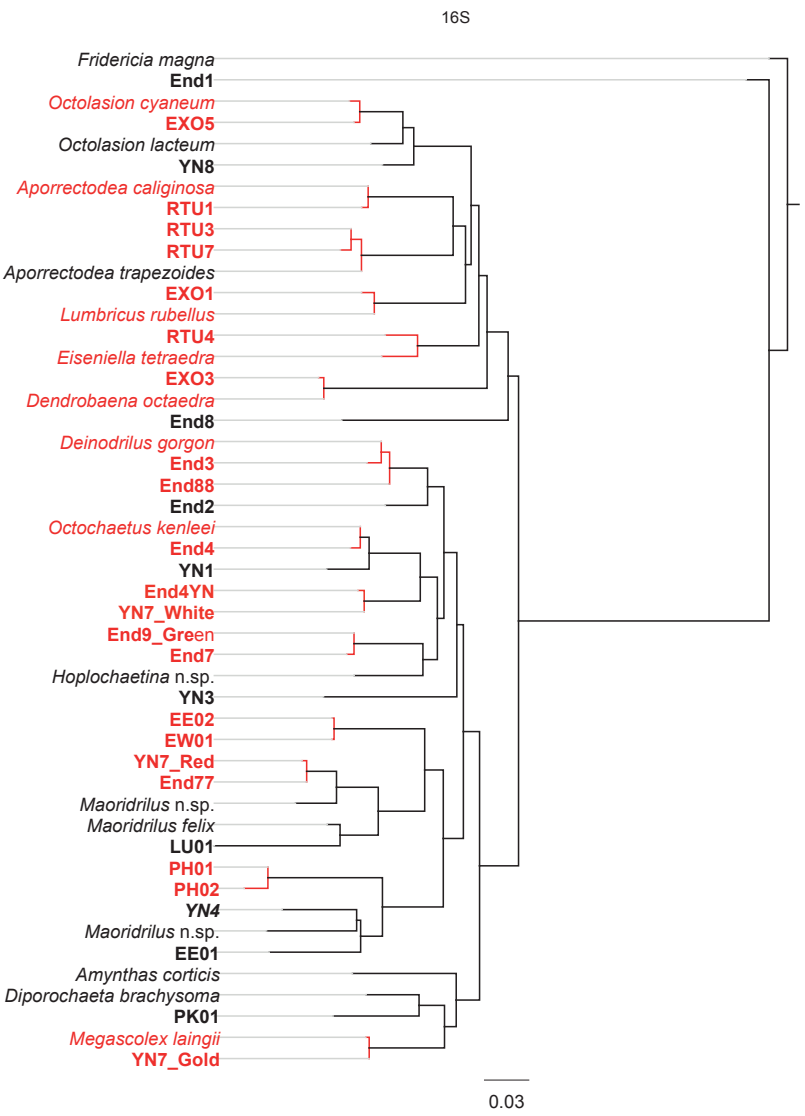

Figure 1. Neighbour joining tree for COI (left) and 16S (right) based on 36 earthworm specimens collected as part of this study (names in bold), along with their closest matches according to a MegaBLAST search against the Genbank library and sequences from Boyer (2013) and Buckley et al. (2011). The enchytraeid species Friderica magna was used as an outgroup. Trees are drawn to scale, with horizontal branch lengths corresponding to percentage difference (see scale). The evolutionary distances were computed using the Kimura 2-parameter substitution model. Specimens linked by red lines are considered to be of the same species based on species identify thresholds of $3 \%$ and $2.8 \%$ for COI and $16 \mathrm{~S}$, respectively. 


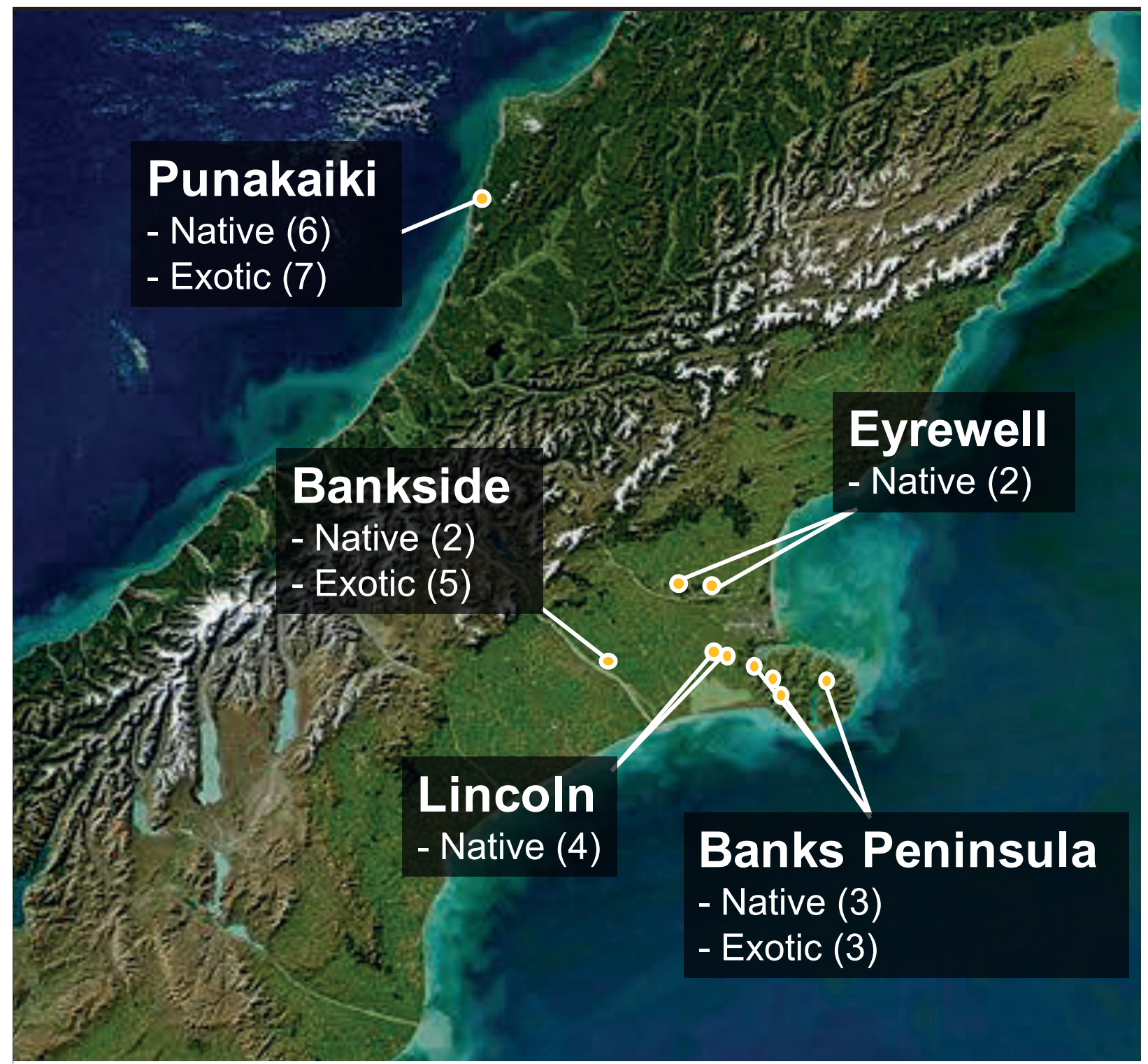

Figure 2. Distribution of native and exotic earthworms sampled in five regions of the South Island (Punakaiki, Bankside, Banks Peninsula, Eyrewell, and Lincoln). Number of species is in brackets. Underlying picture modified from Norman Kuring. commons.wikimedia.org/wiki/File:Turbid_Waters_Surround_New_Zealand__crop.jpg

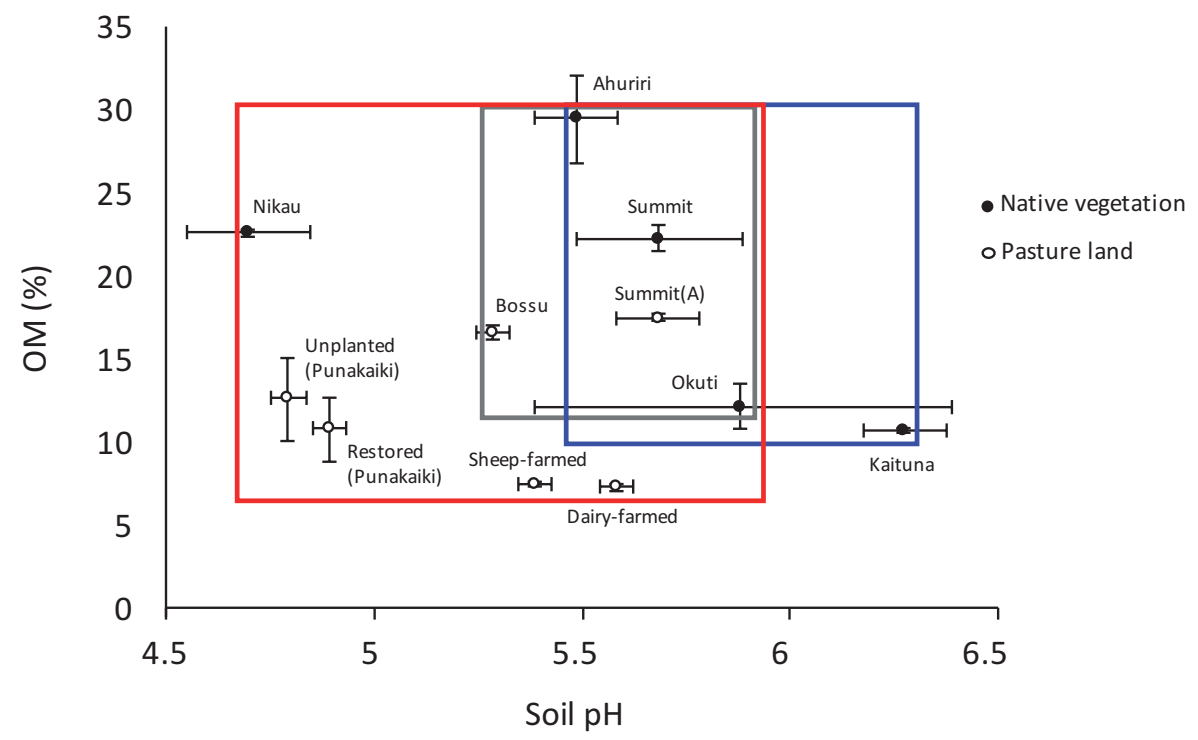

Figure 3. Soil $\mathrm{pH}$ and $\mathrm{OM}$ content at sampling sites in which native earthworms, including Maoridrilus transalpinus (blue box) and Octochaetus multiporus (greybox), and exotic earthworms, including Octolasion cyaneum, Octolasion lacteum, L. rubellus, and Aporrectodae caliginosa (red box), were found to co-occur. Each dot corresponds to values for one sampling site (mean $\pm \mathrm{SE}$ ). In addition to the sites analysed as part of the current study, soil data for sheep- and dairy-farmlands collected as part of previous studies (Fraser et al. 1996; Kim et al. 2015) were added to the graph. 
Table 2. Species affiliation after morphological identification and DNA-based identification. When species could not be identified, specimens were marked with No Match (i.e. the closest hit on Genbank was greater than the species delineation threshold) or X (no DNA sequence available). For clarity, specimens are presented in the same order they appear in the neighbour-joining tree (Fig. 3).

\begin{tabular}{|c|c|c|c|c|}
\hline Specimen name & Morphological ID (if any) & DNA-based identification (COI) & DNA-based identification (16S) & Native / Exotics \\
\hline End1 & & No Match & No Match & Native \\
\hline EXO5 & & Octolasion cyaneum & Octolasion cyaneum & Exotics \\
\hline RTU1 & & Aporrectodea caliginosa & Aporrectodea caliginosa & Exotics \\
\hline RTU3 & & No Match & Aporrectodea trapezoides & Exotics \\
\hline RTU7 & & No Match & Aporrectodea trapezoides & Exotics \\
\hline End8 & & No Match & No Match & Native \\
\hline EXO1 & & Lumbricus rubellus & Lumbricus rubellus & Exotics \\
\hline RTU4 & & $\mathrm{X}$ & Eiseniella tetraedra & Exotics \\
\hline EXO3 & & Dendrobaena octaedra & Dendrobaena octaedra & Exotics \\
\hline End2 & & Amynthas corticis & No Match & Exotics \\
\hline RTU6 & & Dendrodrilus rubidus & $X$ & Native \\
\hline YN7gold & & No Match & Megascolex laingii & Exotics \\
\hline End3 & Deinodrilus & Deinodrilus gorgon & Deinodrilus gorgon & Native \\
\hline End88 & Deinodrilus & Deinodrilus gorgon & Deinodrilus gorgon & Native \\
\hline M7(AB) & Deinodrilus & Deinodrilus gorgon & $\mathrm{X}$ & Native \\
\hline RTU5 & & No Match & $X$ & Native \\
\hline End4 & Octochaetus & Octochaetus kenleei & Octochaetus kenleei & Native \\
\hline U6AB & Octochaetus & Octochaetus kenleei & $X$ & Native \\
\hline YN1 & Octochaetus multiporus & No Match & No Match & Native \\
\hline End4YN & & No Match & No Match & Native \\
\hline YN7_White & & No Match & No Match & Native \\
\hline YN3 & & No Match & No Match & Native \\
\hline EE02 & & $\mathrm{X}$ & No Match & Native \\
\hline EW01 & & $X$ & No Match & Native \\
\hline YN7_Red & Deinodrilus (sp.1) & No Match & No Match & Native \\
\hline End5 & & No Match & $\mathrm{X}$ & Native \\
\hline M4BC & & No Match & $X$ & Native \\
\hline End77 & & No Match & No Match & Native \\
\hline LU01 & Maoridrilus (sp.2) & $\mathrm{X}$ & No Match & Native \\
\hline PH01 & Maoridrilus (sp.1) & $\mathrm{X}$ & No Match & Native \\
\hline PH02 & & $\mathrm{X}$ & No Match & Native \\
\hline YN4 & Maoridrilus transalpinus & No Match & No Match & Native \\
\hline EE01 & & $X$ & No Match & Native \\
\hline End7 & & No Match & No Match & Native \\
\hline End9_Green & & No Match & No Match & Native \\
\hline PK01 & & No Match & No Match & Native \\
\hline
\end{tabular}

Table 3. Physicochemical soil properties (mean $\pm \mathrm{SE}, \mathrm{n}=3$ ) in Punakaiki and Banks Peninsula, where widespread exotic and native species were co-occuring. Native species include $M$. transalpinus and $O$. multiporus and exotic species include O. cyaneum, L. rubellus, and A. caliginosa (c.f. Table 3). EC: Ecectrical conductivity; OM: Organic Matter content.

\begin{tabular}{|c|c|c|c|c|c|c|c|}
\hline \multicolumn{2}{|l|}{ Sample site } & \multirow{3}{*}{$\begin{array}{l}\text { Vegetation } \\
\text { type } \\
\text { Forest } \\
\text { Pasture }\end{array}$} & \multirow{3}{*}{$\begin{array}{l}\begin{array}{l}\text { Soil pH } \\
(1: 5 \mathrm{~W})\end{array} \\
4.7 \pm 0.2 \\
5.44 \pm 0.01\end{array}$} & \multirow{3}{*}{$\begin{array}{l}\begin{array}{l}\mathrm{EC} \\
\left(\mathrm{dS} \cdot \mathrm{cm}^{-1}\right)\end{array} \\
0.19 \pm 0.03 \\
0.04 \pm 0.01\end{array}$} & \multirow{3}{*}{$\begin{array}{l}\text { OM } \\
(\%)\end{array}$} & \multicolumn{2}{|c|}{$\underset{\left(\mathrm{mg} \mathrm{kg}^{-1}\right)}{\mathrm{NH}_{4}-\mathrm{N}-\mathrm{N}}$} \\
\hline & Nikau Reserve & & & & & $20 \pm 1.4$ & $18 \pm 0.5$ \\
\hline Punaka1k1 & Restored land & & & & & $2.0 \pm 1.2$ & $0.7 \pm 0.2$ \\
\hline \multirow{6}{*}{ Banks Peninsula } & Okuti Reserve & Forest & $5.9 \pm 0.5$ & $0.08 \pm 0.02$ & $12 \pm 1.3$ & $4.0 \pm 1.3$ & $9.7 \pm 2.3$ \\
\hline & Southern Summit Road & Forest & $5.7 \pm 0.2$ & $0.10 \pm 0.01$ & $22 \pm 0.8$ & $0.9 \pm 0.3$ & $9.7 \pm 1.3$ \\
\hline & Kaituna Reserve & Forest & $6.3 \pm 0.1$ & $0.06 \pm 0.01$ & $11 \pm 0.1$ & $0.4 \pm 0.2$ & $2.6 \pm 0.1$ \\
\hline & Ahuriri Reserve & Forest & $5.5 \pm 0.1$ & $0.08 \pm 0.01$ & $30 \pm 2.6$ & $0.9 \pm 0.1$ & $3.9 \pm 0.5$ \\
\hline & Bossu Road & Pasture & $5.3 \pm<0.1$ & $0.04 \pm 0.01$ & $17 \pm 0.7$ & $1.1 \pm 0.4$ & $0.4 \pm 0.1$ \\
\hline & Northern Summit Road & Pasture & $5.7 \pm 0.1$ & $0.04 \pm 0.01$ & $18 \pm 0.6$ & $0.5 \pm 0.2$ & $2.1 \pm 0.2$ \\
\hline
\end{tabular}


The Nikau Reserve soil was more acidic and contained higher concentrations of mobile $\mathrm{N}$ (ammonium and nitrate) than soils from Canterbury sites (Table 3 ) and contained the greatest diversity of native earthworms (six taxa). In contrast, less acidic Canterbury soils (Banks Peninsula), which displayed moderate concentrations of mobile $\mathrm{N}$, often harboured only three indigenous species (Maoridrilus spp. and Octochaetus multiporus).

\section{Discussion}

\section{Specimen identification}

A total of 15 Megascolecidae species were identified based on morphology and DNA analyses. Of these, Am. corticis and Me. laingii have been described from Australia but are considered to be exotic in New Zealand (Lee 1959b; Blakemore 2006).

The 17 unidentified specimens (forming eight species according to the DNA analysis) are thought to be undescribed indigenous Megascolecidae as they did not match the morphology of any described species and had no corresponding reference in existing DNA libraries. Therefore, our work confirms previous suggestions that many New Zealand native earthworm species are yet to be described (Boyer et al. 2011; Buckley et al. 2011). Many New Zealand native earthworms have restricted distributions. In this study, none of the native species found at Punakaiki were present in Canterbury, which suggests that the alpine chain between the two regions forms a barrier to earthworm dispersion as illustrated by the distribution of many species (Lee 1959a; SB unpubl. data). One exception is Ma. transalpinus, a widespread species whose distribution spans from the South Island West Coast to Banks Peninsula via Arthur's Pass (SB unpubl. data; Kim et al. 2015) and therefore is now classified as a non-threatened species (Buckley et al. 2015). Another dominant species on the eastern side of the Southern Alps is the deep burrowing endogeic Octochaetus multiporus that is found in Canterbury reserves (Kim et al. 2015) as well as in agricultural pastures on ridges of Banks Peninsula. This species has long been reported to occur in agricultural pastures (Springett et al. 1998). Other native species had more restricted distributions and were only found at one location, or two nearby locations.

With regards to exotic earthworms, nine species were identified, four of which were Lumbricidae: Am. corticis, Ap. caliginosa, D. octaedra, F. magna, L. rubellus, Lumbricidae spp., Me laingii, Octolasion cyaneum, and Octolasion lacteum. These species are known to be widespread in West Coast soils as well as in Canterbury (Table S2; Hahner et al. 2013; Kim et al. 2015; Smith et al. 2016). Sites in the Punakaiki region contained the greatest richness of both native and exotic earthworms, six and eight taxa, respectively. The high OM content of the litter from the local luxuriant broadleaf vegetation at these sites (Hahner et al. 2013; Rhodes et al. 2013) may have promoted a greater richness of native earthworms filling a variety of ecological niches. In the restored agricultural land, the smaller scale, less intensive nature of agriculture when compared to the Canterbury sites may have contributed to a greater diversity of exotic earthworms.

Soil $\mathrm{pH}$ and $\mathrm{OM}$ are both vital factors for earthworm feeding activity and survival (Curry 2004). Two native species (Ma. transalpinus and Octochaetus multiporus) that are known to have a wide geographic distribution (SB; unpubl. data; Lee 1959a; Buckley et al. 2015) were collected at several of the sampling sites. Both of these species occurred in soils that contained similar OM content but had quite different soil $\mathrm{pH}$ (Fig. 3). Temperate climate species are generally found in soil where $\mathrm{pH}$ is between 4.5 and 7.4 (Bouché 1972). Maoridrilus transalpinus was collected from soils of $\mathrm{pH} 5.5$ to 6.3 and Octochaetus multiporus was found in soils of $\mathrm{pH} 5.3$ to 5.9. Springett et al. (1998) also estimated that Octochaetus multiporus was distributed in soils of $\mathrm{pH} 4.9$ in native forests to 5.7 in hill pastures. It seems that the endogeic Octochaetus multiporus was more likely to have stronger resistance to acidification than the anecic species. Exotic species such as L. rubellus, L. terrestris, Ap. caliginosa, A. rosea and Octolasion cyaneum occurred over a much broader range of environmental conditions, including more acidic ( $\mathrm{pH} \mathrm{4.7)}$ and less organic soils $(7.3 \%$ of OM) than those where native species were found. Fraser et al. (1996) reported exotic earthworms in agricultural soils in Canterbury containing $4.3 \%$ to $5.5 \%$ OM.

\section{Conclusion}

A total of 179 indigenous earthworm species belonging to 26 genera of the Megascolecidae family have been described previously from New Zealand (see Table S3 in Supplementary Material). However, many more undescribed species may be present in remote, difficult to access locations or places that simply have never been sampled before. A large number of undescribed species of earthworm have been reported in recent studies (e.g. SB unpubl. data; Waterhouse et al. 2014) and a significant taxonomic effort is required to complete the list of New Zealand native earthworms. The present study illustrates the rudimentary nature of much of our existing knowledge. Even when species have not been described, molecular analyses can provide a first insight into not only their evolutionary history, but also their distribution and environmental requirements. However, widespread sampling, the consolidation of existing DNA databases, and the sequencing of a variety of genetic makers (e.g. 16S, 28S, and COI) will be necessary to make informed decisions for the conservation of native earthworms, of which $59 \%$ of the formally described species are currently classified as 'data deficient' by the Department of Conservation (Buckley et al. 2015).

\section{References}

Blakemore LC 1987. Extractable iron, aluminium and silicon. In: Blakemore LC, Searle PL, Daly BK eds. Methods for chemical analysis of soils. New Zealand Soil Bureau Scientific Report 80. Department of Scientific and Indsutrial Research. Pp. 71-76.

Blakemore RJ 2006. Checklist of New Zealand earthworms updated from Lee (1959). www.annelida.net/earthworm/ Australasian\%20Earthworms/NZ.pdf. 16 p.

Bouché MB 1972. Lumbriciens de France: écologie et systématique. Insitut National de la Recherché Agronomique, Paris. $671 \mathrm{p}$.

Bowie MH, Black L, Boyer S, Dickinson NM, Hodge S 2016. Persistence of biodiversity in a dryland remnant within an intensified dairy farm landscape. New Zealand Journal of Ecology 40: 1-10.

Boyer S, Blakemore RJ, Wratten SD 2011. An integrative taxonomic approach to the identification of three new New 
Zealand endemic earthworm species (Acanthodrilidae, Octochaetidae: Oligochaeta). Zootaxa 2994: 21-32.

Boyer S, Kim Y-D, Bowie MH, Lefort M-C, Dickinson NM 2016. Response of endemic and exotic earthworm communities to ecological restoration. Restoration Ecology 24: 717-721.

Boyer S, Wratten SD, Holyoake A, Abdelkrim J, Cruickshank RH, Forster RJ 2013. Using next-generation sequencing to analyse the diet of a highly endangered land snail (Powelliphanta augusta) feeding on endemic earthworms. PloS One 8: e75962.

Brown SD, Collins RA, Boyer S, Lefort MC, MalumbresOlarte JA, Vink CJ, Cruickshank RH 2012. Spider: an R package for the analysis of species identity and evolution, with particular reference to DNA barcoding. Molecular Ecology Resources 12: 562-565.

Buckley T, Palma R, Johns P, Gleeson D, Heath A, Hitchmough R, Stringer I 2012. The conservation status of small or less well known groups of New Zealand terrestrial invertebrates. New Zealand Entomologist 35: 137-143.

Buckley TR, Boyer S, Bartlam S, Hitchmough R, Rolfe J, Stringer I 2015. Conservation status of New Zealand earthworms, 2014. New Zealand Treat Classification Series 10. Wellington, New Zealand, Department of Conservation. $10 \mathrm{p}$.

Buckley TR, James S, Allwood J, Bartlam S, Howitt R, Prada D 2011. Phylogenetic analysis of New Zealand earthworms (Oligochaeta: Megascolecidae) reveals ancient clades and cryptic taxonomic diversity. Molecular Phylogenetics and Evolution 58: 85-96.

Cameron EK, Bayne EM, Coltman DW 2008. Genetic structure of invasive earthworms Dendrobaena octaedra in the boreal forest of Alberta: insights into introduction mechanisms. Molecular Ecology 17: 1189-1197.

Chang CH, Chen JH 2005. Taxonomic status and intraspecific phylogeography of two ibling species of Metaphire (Oligochaeta: Megascolecidae) in Taiwan. Pedobiologia 49: 591-600.

Chang CH, James S 2011. A critique of earthworm molecular phylogenetics. 9th International Symposium of Earthworm Ecology. Veracruz, Mexico 5th-10th September 2010. Pedobiologia 54: S3-9.

Curry JP 2004. Factors affecting the abundance of earthworms in soils. In: Edwards CA ed. Earthworm ecology. 2nd edn. CRC Press. Pp. 91-113.

Decaëns T, Porco D, Rougerie R, Brown GG, James SW 2013. Potential of DNA barcoding for earthworm research in taxonomy and ecology. Applied Soil Ecology 65: 35-42.

Domínguez J, Aira M, Breinholt JW, Stojanovic M, James SW, Pérez-Losada M 2015. Underground evolution: new roots for the old tree of lumbricid earthworms. Molecular Phylogenetics and Evolution 83: 7-19.

Edgar RC 2004. MUSCLE: multiple sequence alignment with high accuracy and high throughput. Nucleic Acids Research 32: 1792-1797.

Fernández R, Kvist S, Lenihan J, Giribet G, Ziegler A 2014. Sine systemate chaos? A versatile tool for earthworm taxonomy: non-destructive imaging of freshly fixed and museum specimens using micro-computed tomography. PloS One 9: e96617.

Folmer O, Black M, Hoeh W, Lutz R, Vrijenhoek R 1994. DNA primers for the amplification of mitochondrial cytochrome c oxidase subunit I from diverse metazoan invertebrates. Molecular Marine Biology and Biotechnology 3:294-299.
Fraser PM, Williams PH, Haynes RJ 1996. Earthworm species, population size and biomass under different cropping systems across the Canterbury Plains, New Zealand. Applied Soil Ecology 3: 49-57.

Glasby CJ, Read GB, Lee KE, Blakemore RJ, Fraser PM, Pinder AM, Erséus C, MoserWE, Burreson EM, Godevich FR, Davies RW, Dawson EW 2009. Phylum Annelida: bristleworms, earthworms, leeches. In: Gordon DPed. New Zealand inventory of biodiversity. Volume 1: Kingdom Animalia Radiata, Lophotrochozoa, Deuterostomia. Christichurch, New Zealand, Canterbury University Press. Pp. 312-358.

Hahner JL, Bowie MH, Dickinson NM, Smith C, Boyer S, Chassagneux A, Segrestin J, Carter-Brown R, Zhong H, Mountier C 2013. Development and testing indicators of restoration success: Punakaiki coastal restoration project. Lincoln University Wildlife Management Report No. 52. Lincoln, Lincoln University. 211 p.

Kim YN, Robinson B, Boyer S, Zhong HT, Dickinson N 2015. Interactions of native and introduced earthworms with soils and plant rhizospheres in production landscapes of New Zealand. Applied Soil Ecology 96: 141-150.

King RA, Tibble AL, Symondson WO 2008. Opening a can of worms: unprecedented sympatric cryptic diversity within British lumbricid earthworms. Molecular Ecology 17: 4684-4698.

Lee KE 1985. Earthworms, their ecology and relationships with soils and land use. New York, Academic Press. 411 p.

Lee KE 1959a. The earthworm fauna of New Zealand. New Zealand Department of Scientific and Industrial Research Bullentin 130. Wellington, New Zealand. 486 p.

Lee KE 1959b. A key for the identification of New Zealand earthworms. Soil Bureau Publication No. 172. Timaru Herald Print. Reprinted from Tuatara 3: 13-60.

Lee KE 1961. Interactions between native and introduced earthworms. Proceedings of the New Zealand Ecological Society 8: 60-62.

Minamiya Y, Yokoyama J, Fukuda T 2009. A phylogeographic study of the Japanese earthworm, Metaphire sieboldi (Horst, 1883) (Oligochaeta: Megascolecidae), inferences from mitochondrial DNA sequences. European Journal of Soil Biology 45: 423-430.

Novo M, Almodóvar A, Fernández R, Trigo D, Cosín DJD 2010. Cryptic speciation of hormogastrid earthworms revealed by mitochondrial and nuclear data. Molecular Phylogenetics and Evolution 56: 507-512.

Porco D, Decaëns T, Deharveng L, James SW, Skarżyński D, Erséus C, Butt KR, Richard B, Hebert PD 2013. Biological invasions in soil: DNA barcoding as a monitoring tool in a multiple taxa survey targeting European earthworms and springtails in North America. Biological Invasions 15: 899-910.

Rhodes S, Lorenzon K, Hahner JL, Bowie MH, Boyer S, Dickinson NM, Smith C, Sharp D 2013. Punakaiki Coastal Restoration Project: a partnership for closure and restoration of a mineral sands project site in New Zealand. In: Tibbett M, Fourie AB, Digby $\mathrm{C}$ eds. Mine closure 2013 proceedings. Proceedings of the Eighth International Conference on Mine Closure. Perth, Australian Centre for Geomechanics. Pp. 447-463.

Saitou N, Nei M 1987. The neighbor-joining method: a new method for reconstructing phylogenetic trees. Molecular Biology and Evolution 4: 406-425. 
Simon C, Frati F, Beckenbach A, Crespi B, Liu H, Flook P 1994. Evolution, weighting, and phylogenetic utility of mitochondrial gene-sequences and a compilation of conserved polymerase chain reaction primers. Annals of the Entomological Society of America 87: 651-701.

Smith CMS, Bowie MH, Hahner JL, Boyer S, Kim YN, Zhong HT, Abbott M, Rhodes S, Sharp D, Dickinson N 2016. Punakaiki Coastal Restoration Project: a case study for a consultative and multidisciplinary approach in selecting indicators of restoration success for a sand mining closure site, West Coast, New Zealand. Catena 136: 91-103.

Springett JA, Gray RAJ, Barker DJ, Lambert MG, Mackay AD, Thomas VJ 1998. Population density and distribution of the New Zealand indigenous earthworm Octochaetus multiporus (Megascolecidae: Oligochaeta) in hill pastures. New Zealand Journal of Ecology 22: 87-93.

Tamura K, Stecher G, Peterson D, Filipski A, Kumar S 2013. MEGA6: molecular evolutionary genetics analysis version 6.0. Molecular Biology and Evolution 30: 2725-2729.

Waterhouse B, Boyer S, Wratten SD 2014. Pyrosequencing of prey DNA in faeces of carnivorous land snails to facilitate ecological restoration and relocation programmes. Oecologia 175: 737-746.

Editorial board member: Brent Sinclair

Received 15 March 2016; accepted 31 January 2017

\section{Supplementary Material}

Additional supporting information may be found in the online version of this article:

Table S1. Primers used for PCR and DNA sequencing in this study.

Table S2. Distribution of 24 earthworm taxa, 13 endemic and 11 exotic species, collected from soils in New Zealand's South Island.

Table S3. Synthetic classification of New Zealand earthworms based on their family and genus groups.

The New Zealand Journal of Ecology provides online supporting information supplied by the authors where this may assist readers. Such materials are peer-reviewed and copy-edited but any issues relating to this information (other than missing files) should be addressed to the authors. 